\title{
A Western Suburb
}

\section{Isi Unikowski}

A sort of colonisation took place here: people who spoke dialects from the side of languages' mouths arrived along a haft of highway a bow sending semis dopplering southwards, the hollow tin of their passing a single fact queried only by the creeks tendering tithes of sunset in their reeds in fealty to the saltwork's desolate ziggurat, the city's distant barcode.

They laid bricks on clay that rose and fell as if the swamps, newly named in still more ancient dialects clotted again at the doors; fenced off miniature replicas of fields back home places for seeds that had made their own travel plans, espaliered by lore leached by the wrong kind of rain and the wrong kind of heat at the wrong time of year.

They bought grapes from the back of lorries in puddled, pitted vacant lots where factories once stood, from men small and dark as sultanas; sampling the dark little clouds, pushing them askance to the tongue's tip, to the side, splitting and spitting the skins, nodding at those ready for miraculous vintages where each year is worse than the last. 
Wives pined for countries that no longer existed, drawers, like quarrels with history, never quite sorted.

Still, a consolation of sorts took place here: the kids learned the language (but answered in English) handling its inflections like the apparatus of small projects - lugs, flanges, block and tackle, pop rivets, self-tapping screws - by which yards and lives are changed, tinkering in sheds beneath tinkling ironies of hooks, years twisting like children held up for a neighbour.

They left wives and daughters to a frugal grief, the freight train's rhythm dissecting the long nights, a dwindling group of friends huddled on a knoll in that place there, that they made that grew smaller as it grew beside the unrelenting highway, trefoiled and plaited like their stories of priests and documents of children and conscripts crossing the unfathomable fields and forests of the past, stories that I didn't understand, who scoffed at stories often told, who missed the point in the telling; the demijohns half decanted, pulleys half hoisted, the shed door half ajar as though someone who had gone for a spanner was about to come out; buffets and tallboys ageing into their own honey-coloured epochs, only a panel, here or there, split in the uncured circumstances of a dry climate. 